\title{
Peran Perawat Dalam Meningkatkan Penerapan Budaya Keselamatan Pasien di Rumah Sakit
}

\section{Winda Sari Sinaga}

\author{
Windasarisng1701@gmail.com
}

\section{Latar Belakang}

Rumah sakit menjadi salah satu sarana institusi pelayanan kesehatan bagi masyarakat yang pada dasarnya bertujuan untuk menyelamatkan pasien. Rumah sakit wajib memenuhi hak pasien dan pasien memperoleh keamanan dan keselamatan selama berada dalam perawatan di rumah sakit. Keselamatan pasien menjadi hal utama dan terpenting yang perlu diperhatikan dalam memberikan pelayanan kesehatan . Keselamatan pasien dapat diartikan sebagai suatu layanan yang tidak akan merugikan, melukai, dan mencederai pasien, dimana asuhan keperawatan itu diciptakan dan dilakukan lebih aman sehingga kedepannya akan meminimalkan terjadinya insiden kecelakaan kerja dan meningkatkan dan mengutamakan keselamatan pasien. Keselamatan pasien menjadi dasar dari pelayanan kesehatan yang baik di rumah sakit, yang menjadi pertanda dan indikator dalam menilai kualitas dan mutu pelayanan di suatu institusi pelayanan kesehatan tersebut. Maka dari itu rumah sakit wajib melaksanakan pelayanan kesehatan yang aman, bermutu, berkualitas, anti diskriminasi dan efektif dengan prinsip mengutamakan kepentingan pasien. Untuk terus memperhatikan pentingnya keselamatan pasien, diperlukan untuk membangun dan mengembangkan budaya keselamatan pasien sebagai langkah awal dari program pengembangan dan peningkatan penerapan keselamatan pasien.

Budaya keselamatan pasien atau patient safety culture merupakan nilai, persepsi, keyakinan, sikap, kompetensi dan pola perilaku dari setiap individu yang dihasilkan oleh individual dan kelompok yang ditetapkan berdasarkan komitmen dan gaya dari manajemen organisasi kesehatan yang ada di rumah sakit untuk menjamin keselamatan pasien selama perawatan. Penerapan budaya keselamatan pasien akan mendeteksi kesalahan yang akan terjadi atau jika kesalahan telah terjadi budaya keselamatan pasien akan meningkatkan kesadaran untuk mencegah dan melaporkan jika ada kesalahan. 
Keselamatan pasien menjadi gambaran mutu pelayanan kesehatan dari rumah sakit tersebut. Dalam mencapai mutu pelayanan yang baik diperlukan kerja sama, komitmen yang kuat dari individu maupun tim disetiap aspek dirumah sakit. Mutu pelayanan di rumah sakit besar kecilnya juga dipengaruhi dan ditentukan oleh peran perawat. Perawat menjadi salah satu tenaga kesehatan yang bekerja dalam kurun waktu yang lama dan yang paling sering berinteraksi dan melakukan kontak langsung dengan pasien. Perawat harus mengetahui pentingnya peran perawat dalam meningkatkan budaya keselamatan pasien dengan mengetahui serta menerapkan hal-hal yang harus dilakukan dan diterapkan saat bekerja di rumah sakit. Maka dari itu penting bagi perawat untuk mengetahui dan memahami mengenai pentingnya keselamatan pasien. Karna melalui tindakan, perilaku serta sikap perawat menjadi kunci dan point utama keberhasilan penerapan budaya keselamatan pasien atau patient safety culture.

\section{Metode}

Metode yang digunakan oleh penulis dalam jurnal ini adalah Literature review, dengan cara membaca, menganalisis bahan kajian yang relavan dengan pokok bahasan yakni mengenai peran perawat dalam meningkatkan penerapan budaya keselamatan pasien atau patient safety culture. Dimana dengan membaca beberapa jurnal dan bahan kajian terkait lainnya, kemudian menyusun kalimat sendiri yang selanjutnya dituliskan untuk menyelesaikan literature review ini.

Bahan kajian yang digunakan yakni berupa textbook, e-book, buku pedoman terkait, tesis dan jurnal online. Adapun jurnal dan referensi yang digunakan pada literature review ini, diterbitkan paling lama tahun 2012, dengan jumlah minimal yaitu 10 referensi.

\section{Hasil}

Berdasarkan hasil dari pencarian dan pengkajian literature dari berbagai sumber, didapatkan bahwa pentingnya peran perawat dalam penerapan budaya keselamatan pasien. Untuk meningkatkan penerapan budaya keselamatan pasien di rumah sakit pentingnya terlebih dahulu memperhatikan tenaga kesehatan yang bekerja dan melayani pasien secara langsung. Dimana dalam hasil penelitian dari beberapa jurnal bahwa adanya hubungan yang berkaitan antara tingkat 
pengetahuan dan pemahaman perawat dengan penerapan keselamatan pasien, adanya hubungan yang berkaitan antara masa kerja dengan penerapan keselamatan pasien, adanya hubungan yang berkaitan antara budaya kerjasama dalam unit/tim dengan penerapan keselamatan pasien dengan baik.

Berdasarkan dari hasil penelitian pada jurnal yang direview, dari sepeluh jurnal sumber 7 dari 10 jurnal menegaskan bahwa adanya hubungan keterkaitan antara pengetahuan perawat dengan kebiasan dan perilaku dalam menerapkan prinsip patient safety. Tindakan perawat berorientasi dan sejalan dengan pendidikan, pengetahuan yang dimiliki perawat. Salah satunya dari jurnal Pengetahuan penerapan keselamatan (patient safety) pada petugas kesehatan, (2020). Dari hasil penelitiannya dapat disimpulkan bahwa terdapat hubungan yang berkaitan antara pengetahuan perawat dengan penerapan keselamatan pasien. Dimana perawat dengan pengetahuan yang baik mengenai prinsip keselamatan pasien, menerapkan dan melaksanakan prinsip patient safety dengan baik di lingkungan pekerjaannya. Perawat dengan tingkat pendidikan yang baik, pengetahuan yang baik akan lebih mudah dibimbing untuk menerapkan prinsip patient safety dengan baik.

Dari jurnal Pengetahuan Perawat Tentang Keselamatan Pasien Dengan Pelaksanaan Prosedur Keselamatan Pasien Rumah Sakit (KPRS) Di Rumah Sakit Panti Waluya Sawahan Malang, (2015) dan jurnal Pengalaman perawat pelaksana dalam menerapkan keselamatan pasien, (2014) , dari hasil penelitiannya kedua jurbal tersebut dapat disimpulkan bahwa terdapat hubungan antara masa kerja dengan penerapan keselamatan pasien, dimana pada penelitian menunjukkan hasil bahwa hampir seluruh responden yang lebih senior atau lama kerja di Rumah Sakit lebih dari 5 tahun menunjukkan hasil yang baik mengenai penerapan prinsip keselamatan pasien. Pengalaman kerja menjadi penunjang keberhasilan dan ketepatan kerja dari Seorang perawat. Dan pada jurnal Pengetahuan Perawat Tentang Keselamatan Pasien Dengan Pelaksanaan Prosedur Keselamatan Pasien Rumah Sakit (KPRS) Di Rumah Sakit Panti Waluya Sawahan Malang, (2015) kembali diperjelas dan ditegaskan bahwa pentingnya pengetahuan perawat mengenai KPRS atau keselamatan pasien rumah sakit, sehingga perawat dapat menyadari perannya untuk berpartisipasi aktif dalam mewujudkan keselamatan pasien di rumah sakit.

Dari jurnal Analisis budaya organisasi dan budaya keselamatan pasien sebagai langkah pengembangan keselamatan pasien di RSIA Budi Kemuliaan tahun 2014, ( 2015). Dari hasil 
penelitiannya dapat disimpulkan bahwa terdapat keterkaitan hubungan antara budaya kerjasama tim dengan penerapan keselamatan pasien yang baik. Dimana mencakup dua budaya yaitu budaya keselamatan pasien dan budaya organisasi. Di mana budaya keselamatan pasien berkaitan dengan sejauh mana organisasi memprioritaskan dan mendukung peningkatan keselamatan pasien dengan aman gimana organisasi tersebut memiliki komunikasi atas dasar saling percaya presepsi bersama tentang pentingnya keselamatan dan keyakinan pada efektivitas langkah-langkah pencegahan. Sedangkan budaya organisasi berkaitan dengan partisipasi seluruh karyawan di rumah sakit dan kerjasama tim dalam setiap unit untuk menerapkan prinsip keselamatan pasien dengan baik.

Pada jurnal Budaya keselamatan pasien di ruang rawat inap rumah sakit $X$ Kabupaten Jember, ( 2015). Dari hasil penelitiannya kembali dipertegas bahwa keselamatan pasien adalah prioritas utama dan harus dilaksanakan di rumah sakit, indikator dalam penerapan budaya keselamatan adalah kerjasama yang baik, komunikasi, kepemimpinan, dan pelaporan serta respon tidak menghukum atas kesalahan.

\section{Pembahasan}

Keselamatan pasien atau patient safety adalah dasar dari pelayanan kesehatan yang baik. Keselamatan pasien juga menjadi salah satu indikator dalam menilai akreditas institusi pelayanan kesehatan, oleh karena itu keselamatan pasien sangat penting. Keselamatan pasien merupakan suatu sistem pelayanan di Rumah Sakit yang membuat asuhan untuk pasien menjadi lebih aman mencegah terjadinya cedera yang disebabkan oleh kesalahan akibat melaksanakan suatu tindakan atau tidak mengambil tindakan yang seharusnya diambil.

Pada prinsip keselamatan pasien, tindakan yang harus dilakukan menimbang dan berorientasi kepada kemungkinan kerugian dan keuntungan yang akan diterima pasien. Dalam bahasan prinsip keselamatan pasien, tindakan medis dapat dilakukan bila keuntungan bagi pasien lebih besar daripada resiko/kerugian yang akan diterima pasien. Dalam hal ini ini Baik rumah sakit dan seluruh tenaga kesehatan di Rumah Sakit bertanggung jawab atas keselamatan pasien. Keselamatan pasien merupakan tanggung jawab semua pihak yang berkaitan dengan pemberian pelayanan kesehatan. Dimana dalam mencapai tujuan dari penerapan budaya keselamatan pasien, sedikit banyaknya peranan paramedis dan non medis sangat penting karena kinerja mereka akan 
menentukan mutu dan kualitas pelayanan yang akan diberikan yang dirasakan pasien terhadap pelayanan yang didapatkannya. Salah satunya adalah peranan perawat dalam penerapan budaya keselamatan pasien di rumah sakit, yang menjadi salah satu kunci dan komponen penting dalam keberhasilan pelaksanaan keselamatan pasien. Penting untuk bagi seorang perawat untuk memahami dan mengetahui mengenai penerapan keselamatan pasien atau KPRS.

Keselamatan pasien (patient safety) sangat penting bagi petugas kesehatan, dimana keselamatan pasien akan meningkatkan mutu pelayanan kesehatan khususnya di Puskesmas. Hubungan antara pengetahuan dengan penerapan keselamatan pasien (patient safety), dengan penerapan sasaran keselamatan pasien yang baik selalu didasari oleh pengetahuan petugas yang baik, yang diharapkan petugas bisa menerapkan sasaran keselamatan pasien dengan optimal sehingga memberikan kepuasan kepada pasien.

Adanya hubungan pengetahuan petugas kesehatan terutama perawat dengan penerapan keselamatan pasien ataupun patient safety, dimana semakin tinggi pendidikan seseorang maka tingkat pengetahuan orang tersebut akan semakin tinggi dan mudah untuk menerima informasi tentang keselamatan pasien. Namun sebaliknya, bila pendidikan seseorang tersebut rendah akan menghambat perkembangan sikap seseorang terhadap nilai-nilai yang baru diperkenalkan, dimana petugas kesehatan merupakan bagian dari mereka yang memiliki kemampuan dan kewenangan melakukan tindakan medis berdasarkan ilmu yang dimiliki dan diperoleh melalui pendidikan. Pengetahuan tentang keselamatan pasien bagi perawat sangatlah penting dalam mengambil keputusan dan menetapkan intervensi keperawatan bagi pasien. Pengetahuan merupakan faktor penting bagi perawat dalam mengambil keputusan tindakan yang akan dilakukan kepada pasien. Perawat dengan pengetahuan yang baik mengenai keselamatan pasien dapat menerapkan dan melaksanakan prinsip keselamatan pasien dengan baik di tempat kerjanya. Sebaliknya perawat dengan pengetahuan yang kurang baik mengenai prinsip keselamatan pasien, kurang peduli dan tidak menerapkan prinsip patient safety di tempat kerjanya.

Penerapan dan pelaksanaan patient safety sangat bergantung dari pengetahuan petugas kesehatan dimana apabila petugas tersebut menerapkan prinsip patient safety yang didasari oleh pengetahuan yang memadai mengenai keselamatan pasien, maka penerapan prinsip latihan seperti yang dilakukannya tersebut akan bersifat lama ataupun langgeng ( long lasting ), karena didasari dengan pemikiran dan fondasi pengetahuan yang sudah diterima sejak masa pendidikan kemudian 
diterapkan saat di dunia kerja. Namun bila prinsip keselamatan pasien dilakukan atas paksaan dan tekanan dari manajemen rumah sakit maka penerapan budaya keselamatan kerja tersebut tidak akan bertahan lama dan bersifat sementara.

Kurangnya pengetahuan perawat mengenai keselamatan pasien dipengaruhi pengalaman kerja, masa kerja, kurangnya pemberian pendidikan kepada tenaga kesehatan mengenai KPRS. Dan keberhasilan penerapan dan pelaksanaan prinsip keselamatan pasien dipengaruhi masa kerja yang mana juga berkaitan dengan pengalaman kerja yang akan menentukan kinerja dari Seorang perawat. Semakin lama masa kerja maka kecakapan akan lebih baik karena sudah menyesuaikan diri dengan pekerjaannya dan lebih paham mengenai asuhan keperawatan dan betapa pentingnya untuk mengutamakan keselamatan pasien di setiap tindakan keperawatan. Pengalaman kerja perawat dapat mempengaruhi kinerja dalam melakukan tugasnya demikian pula halnya dalam menjaga keselamatan pasien baiknya seorang perawat yang telah berpengalaman akan lebih baik dalam penerapan keselamatan pasien di dunia pekerjaan.

Perawat yang memiliki masa kerja cukup lama, akan lebih memahami bagaimana menerapkan prinsip keselamatan pasien dengan baik, bahwa bukan sebagai peraturan saja tetapi memang menjadi suatu kewajiban. Di mana perawat tersebut akan lebih memperhatikan Asuhan Keperawatan yang akan diberikan, dengan memperhatikan dan melakukan peningkatan beberapa aspek yang mendukung untuk meminimalisir kecelakaan kerja di rumah sakit yang dapat merugikan perawat dan juga pasien. Hal-hal yang dapat dilakukan biasanya yaitu melakukan peningkatan komunikasi secara efektif, melakukan peningkatan keamanan terhadap obat yang perlu diwaspadai, lebih memastikan tindakan bedah yang benar secara letak, prosedur bedah, dan pasien, memahami dan merencanakan tindak pencegahan resiko infeksi terkait pelayanan kesehatan dan merencanakan tindak pencegahan resiko jatuh dan hal-hal lain yang dapat mencelakai atau merugikan pasien.

Aspek lain yang menjadi indikator budaya keselamatan pasien meliputi kerjasama tim, komunikasi, kepemimpinan, dan pelaporan serta respon yang tidak menghukum atas kesalahan. Kerjasama tim merupakan indikator pertama dari budaya keselamatan pasien, di mana dalam melaksanakan asuhan keperawatan kepada pasien perawat akan selalu membutuhkan bantuan dari perawat lain maupun tenaga kesehatan yang lainnya. Bentuk kerjasama tidak hanya berupa saling membantu pekerjaan ketika perawat dihadapkan pada tugas yang sangat banyak dan membutuhkan 
penyelesaian yang sesegera mungkin, namun juga bisa berupa pembagian tugas berdasarkan kelompok kecil atau tim dalam satu unit ruang rawat inap. Perawat adalah petugas kesehatan dengan waktu kerja tertinggi yang memberikan 24 jam pelayanan terus menerus, melakukan kolaborasi dengan tim kesehatan lain dan oleh karena hal tersebut dapat menyebabkan risiko terjadinya cidera. Keterlibatan banyak profesi selain tenaga perawat dalam melakukan asuhan keperawatan dapat menimbulkan atau berisiko terjadi cidera jika dilakukan tidak dengan komunikasi dan koordinasi yang tepat, kecelakaan kerja seperti cidera dapat dihindari jika perawat selalu menjaga hubungan baik dengan sesama perawat dan petugas kesehatan lainnya, dan menjaga keharmonisan di lingkungan kerja atau suasana hati untuk mencapai pelayanan kesehatan. Maka kerja sama tim sangat erat hubungan dan keterkaitanya dengan komunikasi sesama tim medis.

Komunikasi yang baik dan benar perlu dilakukan untuk mengkoordinasikan asuhan keperawatan yang melibatkan banyak profesi selain profesi perawat. Komuniasi dalam praktek keperawatan merupakan elemen penting bagi perawat dalam melaksanakan asuhan keperawatan untuk mendapatkan hasil yang optimal. Perawat memiliki peran yang paling dominan dalam mencegah terjadinya kesalahan dalam pengobatan, termasuk pelaporan insiden, mendidik diri sendiri dan perawat lain tentang penting komunikasi, memberikan rekomendasi untuk perubahan prosedur dan kebijakan serta keterlibatan dalam melakukan identifikasi permasalahan. Kesalahan medis jarang disebabkan oleh faktor kesalahan manusia secara individual, tetapi lebih karena kesalahan pada sistem komunikasi yang menyebabkan terputusnya rantai informasi, hal ini menunjukkan pentingnya menjalin komunikasi dengan baik agar informasi yang disampaikan tidak terputus dan mengakibatkan kerugian pada pasien. Informasi tentang keselamatan pasien perlu diketau oleh semua perawat yang memberikan asuhan keperwatan hal tersebut berfungsi untuk mencegah perawat melakukan tindakan yang dapat menyebabkan cidera pada pasien.

Selain kerjasama tim dan komunikasi yang baik dalam tim kepemimpinan juga berpengaruh terhadap keselamatan pasien. Pemimpin harus mampu menjaga dan menjadi di agen perubahan bagi anak buahnya dalam melaksanakan program keselamatan pasien. Pemimpin rumah sakit ataupun pemimpin dari setiap unit pelayanan menjadi pendorong dan yang menjamin implementasi program keselamatan pasien secara terintegrasi dalam organisasi Rumah Sakit. Melalui kepemimpinan yang baik akan terbangun komitmen dan fokus yang kuat serta jelas yang 
mendukung staff dan anak buah lainnya untuk menjalankan program keselamatan pasien secara berkesinambungan, memprioritaskan keselamatan pasien dalam setiap pengambilan keputusan dan tindakan sehingga menekan atau mengurangi kejadian yang tidak diharapkan yang bisa merugikan pasien. Pemimpin yang baik juga akan mendorong dan menumbuhkan komunikasi dan kerjasama yang baik di timnya. Fungsi pemimpin subunit/perbagian departemen sangat penting untuk memotivasi bawahannya dan memberikan serta membagi pengetahuan kepada sesama tenaga kesehatan terutama yang masih memiliki masa kerja yang relatif tingkat. Kepemimpinan yang baik akan berkaitan dengan respon tidak menghukum terhadap kesalahan yang dilakukan anak buahnya, artinya ketika ada pelaporan terhadap insiden keselamatan pasien masalah tersebut akan ditindaklanjuti untuk memperbaiki kesalahan dan mencari akar permasalahan dan tidak untuk menghukum perawat yang melakukan kesalahan tersebut. Akan tetapi lebih mekankan pada upaya mencari apa yang salah, mengapa kesalahan tersebut dapat terjadi, dan apa yang bisa dilakukan untuk memperbaiki kesalahan. Namun dari pelaporan insiden masalah tersebut menjadi pembelajaran agar insiden tersebut tidak terulang lagi dan perawat yang melakukan kesalahan diberikan pendidikan dan pengetahuan lebih lanjut mengenai prinsip keselamatan pasien.

Maka dari hasil review dari beberapa jurnal sumber kajian dapat dipertegas kembali bahwa untuk meningkatkan penerapan budaya keselamatan pasien di rumah sakit diperlukan kerjasama dari seluruh aspek struktur organisasi yang berada di rumah sakit, mulai dari tingkat manajemen rumah sakit, setiap kepala departemen dan kepala ruangan, ketua tim dan dokter pelaksana, ketua tim dan perawat pelaksana, dan seluruh tenaga kesehatan yang bekerja di Rumah Sakit serta seluruh tenaga non medis yang bekerja di rumah sakit untuk mencapai tujuan yakni kepuasan pasien terhadap pelayanan kesehatan yang diberikan dan yang paling utama ialah menjaga keselamatan pasien sampai akhirnya pasien keluar dan selesai menjalani program perawatannya di rumah sakit tesebut.

\section{Penutup}

Dalam upaya meningkatkan penerapan budaya keselamatan pasien di rumah sakit diperlukan kerjasama dari seluruh aspek baik tim dan perseorangan yang bekerja di rumah sakit. Salah satunya ialah tenaga medis yakni perawat. Perawat berperan penting dalam meningkatkan penerapan budaya keselamatan pasien di rumah sakit, dan perawat memiliki peran dominan dalam 
mencegah terjadinya kesalahan dalam pengobatan dan pemberian tindakan yang tentunya berkaitan dengan keselamatan pasien. Peran perawat dalam peningkatan penerapan budaya keselamatan pasien dapat dimulai dari peningkatan pengetahuan perawat mengenai keselamatan pasien di rumah sakit, kerja sama dan komunikasi tim yang baik serta kepemimpinan organisasi di rumah sakit yang mendukung program K3 yakni keselamatan pasien dan keselamatan kesehatan kerja. Sehingga rencana peningkatan penerapan budaya keselamatan pasien di rumah sakit akan sejalan dan sesuai dengan tujuan dan meningkatkan angka keselamatan pasien yang tentunya menjadi gambaran mutu dan kualitas pelayanan dari rumah sakit tersebut.

\section{Daftar Pustaka}

Sriningsih Nining, dkk. 2020. Pengetahuan penerapan keselamatan (patient safety) pada petugas kesehatan. Artikel Penelitian Jurnal Kesehatan. 9 (1).

Harus Bernadeta Dece, dkk. 2015. Pengetahuan Perawat Tentang Keselamatan Pasien Dengan Pelaksanaan Prosedur Keselamatan Pasien Rumah Sakit (KPRS) Di Rumah Sakit Panti Waluya Sawahan Malang. Jurnal CARE. 3 (1) : 25-32.

Simamora, R. H., \& Fathi, A. (2019). The Influence Of Training Handover Based SBAR Communication For Improving Patients Safety. Indian journal of public health research \& development, 10(9), 1280-1285.

Iriviranty Afrisya. 2015. Analisis budaya organisasi dan budaya keselamatan pasien sebagai langkah pengembangan keselamatan pasien di RSIA Budi Kemuliaan tahun 2014. Jurnal ARSIJurnal Administrasi Rumah Sakit. 1(3) : 196-206.

Isnaini Nur Mahya, dkk. 2014. Pengalaman perawat pelaksana dalam menerapkan keselamatan pasien. Jurnal Managemen Keperawaatan. 2(1) : 30-37.

Herawati Yennike Tri. 2015. Budaya keselamatan pasien di ruang rawat inap rumah sakit $\mathrm{X}$ Kabupaten Jember. Jurnal IKESMA. 11(1) : 52-60.

Firawati. 2012. Pelaksanaan Program Keselamatan Pasien di RSUD Solok. Jurnal Kesehatan Masyarakat. 6 (2).

Nazirah Riska, Yuswardi. 2017. Perilaku Perawat Dalam Penerapan Manajemen Kesehatan dan Keselamatan Kerja (K3) di Aceh. Idea Nursing Journal. 8 ( 3 ). 
Rachmawati Alifa Rizqia, dkk. 2017. Analisis Pelaksanaan Tujuh Langkah Menuju Keselamatan Pasien Di Rumah Sakit Islam Sultan Agung Semarang. Jurnal Kesehatan Masyarakat (e-journal). $5(1): 1-8$.

Mudayana, A. A.. 2015. Pelaksanaan Patient Safety Oleh Perawat di RS PKU Muhammadiyah Yogyakarta. Jurnal Kesehatan Samodra Ilmu. 6 (2).

Ulumiyah, H. N.. 2018. Meningkatkan Mutu Pelayanan Kesehatan Dengan Penerapan Upaya Keselamatan Pasien Di Puskesmas. Jurnal Administrasi Kesehatan Indonesia. 6( 2). 